\title{
Review about the importance of skin mucus from asian swamp eel (Monopterus albus)
}

Keywords: monopterus albus, insect larvae, shrimps, cray fish, frogs, tadpoles

\section{Taxonomy and distribution of asian swamp eel}

Asian swamp eel, Monopterus albus belongs to the family synbranchidae under the order synbranchiformes. ${ }^{1}$ It is originating in the East and Southeast Asian countries. ${ }^{2}$ It is feed on small fishes, prawns, worms, snails, insect larvae, shrimps, cray fish, frogs and tadpoles. It was also found that swamp eel consumed phytoplankton, benthic algae and organic debris. ${ }^{3}$ It lives in muddy areas, rice paddies, ponds and slow flowing currents, it has a unique morphological elongated body, similar to snake, covered with mucus without scales or fins, it has the ability to breathe air through the buccal mucosa, and it is hermaphrodite as it can undergo sex reversal naturally, ${ }^{4,5}$ but the exact mechanism still unknown. ${ }^{6}$

\section{Biological activities of asian swamp eel skin mucus}

Asian swamp eel mucus is secreted by the epidermal goblet cells in the epidermis which composed from inorganic salts, immunoglobulins, lipids and gel forming macromolecules such as mucins, and other glycoproteins suspended in water, ${ }^{7}$ which giving the mucus lubricating properties. ${ }^{8}$ The mucus layer is continuously replaced which protect the eel from stable colonization by bacteria, parasites and fungi. ${ }^{9}$ The functional properties of the mucus depend on its ability to form a gel on the epithelial surface, ${ }^{10}$ which produce antimicrobial molecules serve as the first line of a host's defense against microbial invasion. ${ }^{11}$ The mucopolysaccharides in the mucus has a high value for immunoprotection and defense mechanism. ${ }^{12,13}$ It has been proven that mucin has potential of antimicrobial and noxious properties,${ }^{14}$ as it plays an important role to protect the eel from pathogens. ${ }^{15}$ Overall mucus layer on the surface of eel functions as a physical and biochemical barrier between eel and its environment. ${ }^{16}$

\section{Antimicrobial activities}

Asian swap eel skin mucus contains antimicrobial peptides cause formation of pores in bacterial membranes which leads to bacterial killing, moreover the mucus has anti-bacterial proteins can affect essential bacterial functions by binding to DNA in the bacteria. ${ }^{17,18}$ It has been demonstrated that mucus prevents the colonization of pathogenic micro-organisms on the surface of the eel. ${ }^{19} M$ albus swamp eel skin mucus has a performance assessment for determining malachite green, ${ }^{20}$ which has antimicrobial properties. ${ }^{21}$ It has been also claimed that the soluble and insoluble proteins in the mucus are responsible for the Antimicrobial and haemolytic activities. ${ }^{22}$

\section{Antibacterial activities}

Antibacterial proteins/peptides have been found in the skin mucus of different fish species including Asian swamp eel. ${ }^{23-26}$ Different extracts have been used of M albus to test the antibacterial activity and the results showed a significant bacteriostatic effect of these extracts. ${ }^{27}$

\author{
Volume 7 Issue 5 - 2018
}

\author{
Ayah Rebhi Hilles,' Syed Mahmood, ,2,3 Mohd \\ Arifin Kaderi,' Ridzwan Hashim' \\ 'Department of Biomedical Sciences, International Islamic \\ University Malaysia, Malaysia \\ ${ }^{2}$ Department of Pharmaceutical Engineering, University Malaysia \\ Pahang, Malaysia \\ ${ }^{3}$ Centre of Excellence for Advanced Research in Fluid Flow \\ (CARIFF), University Malaysia Pahang, Malaysia
}

Correspondence: Ayah Rebhi Hilles, Department of Biomedical Sciences, International Islamic University Malaysia, Malaysia,Email ayah.hilles90@gmail.com

Received: September 19, 2018 | Published: October 05, 2018

\section{Antifungal activities}

It has been reported that $M$ albus extracts have higher anti-fungal activity as compared to ampicillin. ${ }^{27}$ It has been proven also that eel skin mucus extract from Asian local swamp eel, Malbus has antifungal activities against Candida krusei, Candida albicans, Cryptococcus neoformans and Fusarium species. ${ }^{28}$

\section{Anticancer activities}

It has been showed that the eel skin mucus generally considers as a promising candidate to be used as anti-tumor therapy because of induction mitochondria-mediated apoptosis through membrane interaction against K562 human leukemia cells. ${ }^{29}$ Specifically, $M$ albus showed higher levels of antiproliferative activity.

\section{Acknowledgements}

None.

\section{Conflict of interest}

The authors declared that there is no conflict of Interest.

\section{References}

1. Rossen DE, Greenwood PH. A fourth neotropical species of Synbranchid eel and the phylogeny and systematics of Synbranchiform fishes. Bulletin of American Museum of Natural History. 1976;157:1-69.

2. Collins TM, Trexler JC, Nico LG, et al. Genetic diversity in a morphologically conservative invasive taxon: multiple introductions of swamp eels to the Southern Unites States. Conservation Biology. 2002;16(4):1024-1035.

3. Yang D, Chen F, Li D, et al. Preliminary study on the food composition of mudeel, Monopterus albus. Acta Hydrobiol Sin/Shuisheng Shengwu Xuebao. 1977;21:24-30.

4. Liem KF. Sex reversal as a natural process in the synbranchiform fish Monopterus albus. Copeia. 1963;303-312. 
5. Chan STH, Phillips JG. The structure of the gonad during natural sex reversal in Monopterus albus (Pisces: Teleostei). Journal of Zoology. 1967;151(1):129-141.

6. Ayah RH, Syed M, Ridzwan H. The Secret Behind the Natural Sex Reversal in Rice Field Eel (Monopterus albus) Remains Unknown. Adv Complement Alt Med. 2018;2(2).

7. Bragadeeswaran S, Thangaraj S. Hemolytic and antibacterial studies on skin mucus of eel fish, Anguilla anguilla Linnaues, 1758. Asian J Biol Sci. 2011;4:272-276.

8. Pearson J, Brownlee IA. A surface and function of mucosal surface. Colonization of the mucosal surface; 2005.

9. Villarroel F, Bastías A, Casado A, et al. A polipoprotein AI, an antimicrobial protein in Oncorhynchus mykiss: evaluation of its expression in primary defence barriers and plasma levels in sick and healthy fish. Fish \& shellfish immunology. 2007;23(1):197-209.

10. Martínez-Antón A, Debolos C, Garrido M, et al. Mucin genes have different expression patterns in healthy and diseased upper airway mucosa. Clinical \& Experimental Allergy. 2006;36(4):448-457.

11. Manivasagan P, Annamalai N, Ashok kumar S, et al. Studies on the proteinaceous gel secretion from the skin of the catfish, Arius maculatus (Thunberg, 1792). African Journal of Biotechnology. 2009;8(24).

12. Watanabe M, Nakamura O, Muramoto $\mathrm{K}$, et al. Allosteric regulation of the carbohydrate-binding ability of a novel congereel galectin by Dmannoside. J Biol Chem. 2012;287(37):31061-31072.

13. Dirks RP, Burgerhout E, Brittijn SA, et al. Identification of molecular markers in pectoral fin to predict artificial maturation of female European eels (Anguilla anguilla). Gen Comp Endocrinol. 2014;204:267-276.

14. Knouft JH, Page LM, Plewa MJ. Antimicrobial egg cleaning by the fringed darter (Perciformes: Percidae: Etheostoma crossopterum): implications of a novel component of parental care in fishes. Proceedings of the Royal Society of London B: Biological Sciences. 2017;270(1531):2405-2411.

15. Yan Q, Zhao M, Wang X, et al. Adhesion mechanisms of Vibrio fluvialis to skin mucus of Epinephelus awoara. Chinese Journal of Oceanology and Limnology. 2010;28(2):260-266.

16. Palaksha KJ, Shin GW, Kim YR, et al. Evaluation of non-specific immune components from the skin mucus of olive flounder (Paralichthys olivaceus). Fish \& shellfish immunology. 2008;24(4):479-488.

17. Hancock RE, Chapple DS. Peptide antibiotics. Antimicrobial agents and chemotherapy. 1999;43(6):1317-1323.
18. Friedrich CL, Moyles D, Beveridge TJ, et al. Antibacterial action of structurally diverse cationic peptides on gram-positive bacteria. Antimicrobial agents and chemotherapy. 2003;44(8):2086-2092.

19. Dalmo RA, Ingebrigtsen K, Bøgwald J. et al. Non-specific defence mechanisms in fish, with particular reference to the reticuloendothelial system (RES). Journal of Fish Diseases. 1997;20(4):241-273.

20. Wong YC, Cheung TC. Performance assessment for determining malachite green and leucomalachite green in swamp eel (Monopterus albus) muscle using assigned reference values in a proficiency test. Food Additives and Contaminants. 2009;26(11): 1472-1481.

21. Srivastava S, Sinha R, Roy D. Toxicological effects of malachite green. Aquatic toxicology. 2004;66(3):319-329.

22. Uthayakumar V, Ramasubramanian V, Senthilkumar D, et al. Biochemical characterization, antimicrobial and hemolytic studies on skin mucus of fresh water spiny eel Mastacembelus armatus. Asian Pacific Journal of Tropical Biomedicine. 2012;2(2):S863-S869.

23. Ebran N, Julien S, Orange N, et al. Pore-forming properties and antibacterial activity of proteins extracted from epidermal mucus of fish. Molecular \& Integrative Physiology. 1999;122(2):181-189.

24. Ebran N, Julien S, Orange N, et al. Isolation and characterization of novel glycoproteins from fish epidermal mucus: correlation between their pore-forming properties and their antibacterial activities. Biochimica et Biophysica Acta (BBA)-Biomembranes. 2000;1467(2):271-280.

25. Cho Park, Kim Lee, Kim. Confirmed the presence of the antimicrobial peptide parasin I in Japaneseeel amongst other fish species. China; 2002.

26. Cho JH, Park IY, Kim HS, et al. Cathepsin D produces antimicrobial peptide parasin I from histone $\mathrm{H} 2 \mathrm{~A}$ in the skin mucosa of fish. The FASEB Journal. 2002;16(3):429-431.

27. Atif AB, Zahri MK, Esa AR, et al. Comparative analysis of the antibacterial, antifungal, antiproliferative and cyclic response element (CRE) induced expression of downstream luc gene activities of Monopterus albus and Channa straitus extracts. USA. 2005;5(1):42-47.

28. Nor M, Ikram NM, Hashim R. A preliminary screening of antifungal activities from skin mucus extract of Malaysian local swampeel (Monopterus albus). International Research Journal of Pharmacy and Pharmacology. 2013;3(1):1-8.

29. Kwak CH, Lee SH, Lee SK, et al. Induction of Apoptosis and Antitumor Activity of Eel Skin Mucus, Containing Lactose-Binding Molecules, on Human Leukemic K562 Cells. Marine drugs. 2015;13(6):3936-3949. 